Review

\title{
Management Practices and Their Potential Influence on Johne's Disease Transmission on Canadian Organic Dairy Farms-A Conceptual Analysis
}

\author{
Laura Pieper ${ }^{1}$, Ulrike Sorge ${ }^{2}$, Ann Godkin ${ }^{3}$, Trevor DeVries ${ }^{4}$, Kerry Lissemore ${ }^{1}$ and \\ David Kelton ${ }^{1, *}$
}

1 Department of Population Medicine, University of Guelph, Ontario, ON N1G 2W1, Canada; E-Mails: pieperl@uoguelph.ca (L.P.); klissemo@ovc.uoguelph.ca (K.L.)

2 Department of Veterinary Population Medicine, University of Minnesota, St. Paul, MN 55108, USA; E-Mail: sorge@umn.edu

3 Veterinary Science and Policy Group, Ontario Ministry of Agriculture and Food (OMAF), Ontario, ON NOB 1S0, Canada; E-Mail: ann.godkin@ontario.ca

4 Department of Animal and Poultry Science, University of Guelph, Ontario, ON N1G 2W1, Canada; E-Mail: tdevries@uoguelph.ca

* Author to whom correspondence should be addressed; E-Mail: dkelton@ovc.uoguelph.ca; Tel.: +1-519-824-4120 (ext. 54808); Fax: +1-519-763-8621.

External Editor: Marc A. Rosen

Received: 2 September 2014; in revised form: 4 November 2014 / Accepted: 5 November 2014 / Published: 18 November 2014

\begin{abstract}
Johne's disease (JD) is a chronic, production-limiting disease of ruminants. Control programs aiming to minimize the effects of the disease on the dairy industry have been launched in many countries, including Canada. Those programs commonly focus on strict hygiene and management improvement, often combined with various testing methods. Concurrently, organic dairy farming has been increasing in popularity. Because organic farming promotes traditional management practices, it has been proposed that organic dairy production regulations might interfere with implementation of JD control strategies. However, it is currently unclear how organic farming would change the risk for JD control. This review presents a brief introduction to organic dairy farming in Canada, JD, and the Canadian JD control programs. Subsequently, organic practices are described and hypotheses of their effects on JD transmission are developed. Empirical research is needed, not only to
\end{abstract}


provide scientific evidence for organic producers, but also for smaller conventional farms employing organic-like management practices.

Keywords: organic farming; paratuberculosis; control program; disease prevention; dairy cows

\section{Introduction}

The organic dairy sector is a rapidly growing industry in Canada [1]. To receive organic certification, farmers must adjust their management practices to comply with the national Canadian Organic Standards (COS) [2]. Additionally, some organic farmers further employ altered management practices reflecting their beliefs. Due to restrictions that the standards impose on treatment options for diseased animals, organic farms need to place more emphasis on prevention rather than treatment of diseases [2]. However, the unique circumstances on organic farms have the potential to modify infectious disease transmission risks among and within herds.

The aim of this review is to raise awareness about the risks for Johne's disease (JD) transmission and opportunities for its prevention on organic dairy farms in Canada, with the objective of identifying areas that might need specific research and management attention. Throughout this review, the terms JD positive or JD negative were used to describe the status of individual animals or herds, indicating that positive or negative test results (e.g., by fecal culture or ELISA) were observed, depending on the study cited. This review focuses on organic dairy cattle farming; organic dairy sheep, dairy goat, and beef cattle farming were omitted. An organic dairy farm was defined as a farm certified under organic regulations in the respective country. Parts of the COS and organic practices were compared with current recommendations for JD prevention and control. Comments were made about how, in the authors' opinion, the risk for disease transmission could be impacted under Canadian organic dairy farming conditions.

\section{Canadian Organic Dairy Farming}

\subsection{Canadian Organic Standards}

Organic farming evolved as a counter movement to the increased use of technology in farming, at the beginning of the 20th century [3]. Organic production is now formally legislated in Canada by the regulations CAN/CGSB-32.310-2006 Organic Production Systems-General Principles and Management Standards (COS) [2], the CAN/CGSB-32.311-2006 Organic Production Systems-Permitted Substances Lists [4], and the Organic Products Regulations, 2009 (SOR/2009-176) [5]. To sell organic milk inter-provincially, internationally, or to use the organic logo farmers must be certified under these regulations. The specifically stated aim of organic production is to optimize productivity in diverse situations and design a sustainable system within the agro-ecosystem. It focuses on protecting the environment, minimizing soil degradation, maintaining biological diversity, recycling resources within the farm, and caring for animals to promote their health and to meet their behavioral needs [2].

Currently, Canadian Food Inspection Agency (CFIA) designated Conformity Verification Bodies accredit third party certifiers to ensure the uniform application of the COS [5]. However, since the COS 
were only implemented in 2006 and the Organic Products Regulation in June 2009, many producers, veterinarians and advisors are not yet familiar with the specifics. For example, it is widely believed among dairy professionals that antibiotic therapy is entirely forbidden for organic dairy production. However, the COS state that necessary treatment should not be withheld from sick animals. In emergency situations when alternative treatments (herbal or homeopathic) are ineffective, antibiotics can be used for up to two cases per lactation and the treated animal can return into organic production after 30 days or twice the legal withdrawal time, whichever is longer. Prophylactic or metaphylactic antibiotics are not allowed [2]. Similar regulations are in place for hormone or parasiticide treatments. Furthermore, veterinarians are supposed to play a key role in disease prevention and control, and written instructions for the chemical allopathic treatments have to be given to the producer [2]. Because COS put restrictions on the treatment options for sick animals, farmers are required to focus more on prevention rather than treatment of diseases [2].

Certified organic production animals have to be fed organic feed. The COS limit the amount of grain fed to herbivores and specify that the forage intake from grazing has to be at least $30 \%$ of the dry matter consumed during the pasture season. In the winter, cows must have regular exercise preferably daily or at the very least twice per week.

Housing and nutrition for dairy calves is also regulated. Organically raised calves have to receive natural cow milk until weaning; however, suckling from the dam is not a requirement in the COS. Theoretically, organic milk replacer could be fed in cases of emergency, but it is currently unavailable. There is also no specification that calves have to stay with the dam after calving; but, group housing with other calves after the first three months of life is required. Similar to adult dairy cows, dairy heifers, older than nine months of age, have to be turned out on pasture, depending on the season [2].

\subsection{Organic Dairy Industry}

The organic dairy industry in Canada has been growing steadily for more than a decade. Between 2000 and 2010, organic milk production has increased by almost 10-fold. At the same time, the number of producers has increased gradually (Figure 1). In 2011/2012, 1.2\% of the total national milk output was produced by 218 certified organic farmers. The province with the greatest production of organic milk and the highest number of organic dairy farmers is Quebec, followed by Ontario, British Columbia, and Alberta. British Columbia has the largest proportion of milk produced organically $(2.8 \%)$, followed by Alberta (1.4\%), Quebec (1.3\%), and Ontario (1.0\%) [1].

This production does not necessarily reflect the amount of milk processed to produce organic foods and beverages. Due to underdeveloped infrastructure in parts of the country, some organic milk still goes into the conventional milk processing stream. In Ontario, about $10 \%$ of organically produced milk is processed as conventional milk and producers do not receive the incentive for organic milk, even though the organic milk market is relatively well established. Furthermore, small amounts of organic milk are imported, mainly from the USA [1].

Although producers are rewarded for their efforts to produce organic milk with premium payments for milk classes 1 and 2 of $\$ 0.25$ to $\$ 0.30$ CAD per litre (depending on the province), they often need to pay $\$ 0.08$ to $\$ 0.12 \mathrm{CAD}$ per litre in additional administration and transportation fees that are commonly deducted from this premium prior to payment [1]. 
Figure 1. Growth of organic dairy industry between 2000 and 2010. (Data from [6]).

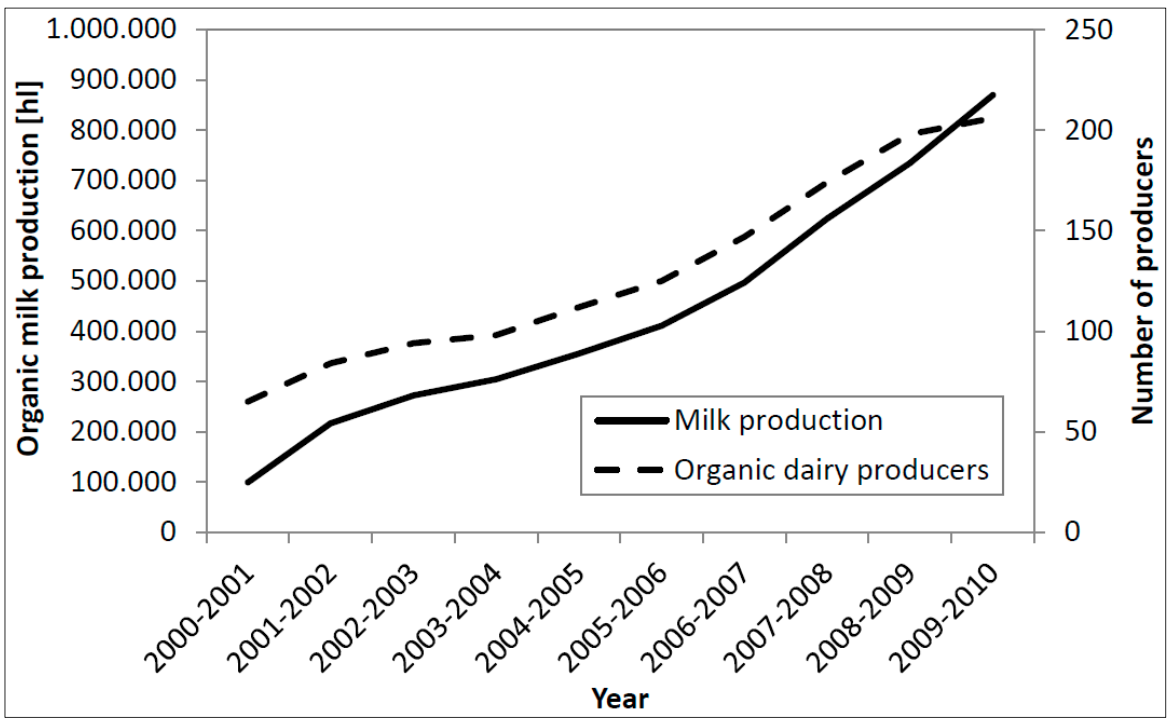

\subsection{Scientific Investigations on Organic Dairy Production}

Scientific literature targeting organic dairy farming in Canada is sparse. The majority of published articles focus on economic or environmental impacts of organic dairy farming. One article [7] investigates breeding values for organic dairy cattle. To date, little has been published about animal health or welfare on organic dairy farms in Canada.

In Ontario, organic farms usually have lower milk production per cow and per hectare than conventional herds [8]. These findings are supported by the earlier Ontario study from Stonehouse et al. [9] but not by Ogini et al. [10]. Ogini et al. [10] and Stonehouse et al. [9] showed that although organic farmers have fewer crop sales revenues, or fewer crop and milk sales revenues per hectare, respectively, the majority of them are better off economically because they tend to rely more heavily on self-sufficiency rather than on off-farm inputs. This self-sufficiency is represented, for example, in raising their own replacement stock, growing their own livestock feed, as well as no use of chemical fertilizer, herbicides, or pesticides.

In multiple studies, it was reported that Ontario organic farms have a high proportion $(>50 \%)$ of their land base utilized for forage production for livestock [7,8,11]. Farm nutrient (N, P, K) surpluses per hectare per year were lower than reported on conventional farms, and soil $\mathrm{P}$ levels were low on approximately half of the farms whereas exchangeable $\mathrm{K}$ levels were moderate to high on all farms. Some organic farms showed a negative $\mathrm{P}$ balance, which indicates that depletion of soils could happen if insufficient nutrient supplementation is done [8].

To optimize nutrient input and utilization of the soil, organic farms employ long rotation cycles including pasture, legumes and small grains, instead of the simple corn-soy rotations which are used on many conventional farms. They also compost the liquid and solid manure before applying it to the crops [11]. Organic farmers tend to preserve, or even build up, soil organic matter to increase soil fertility, and retain water [12].

Milk yield on organic farms is usually lower and the herd size is comparable or smaller than on conventional farms [7-9]. An indicator for milk quality is the number of white blood cells in the milk, commonly referred to as somatic cell count or SCC, with low SCC indicating good milk quality. 
Rozzi et al. [7] reported the average SCC of organic herds was 309,000 cells $/ \mathrm{mL}$, or about 50,000 cells $/ \mathrm{mL}$ higher than on conventional farms, and there was an inverse relationship between milk yield and SCC. Therefore, organic herds with intensive management and high milk yield were found to have lower SCC than organic herds with less intensive management and lower milk yield. In a survey of 8 farmers in western Ontario, the most commonly farmer-reported livestock diseases were mastitis, milk fever, and calf pneumonia. Interestingly, all eight of those farmers used homeopathy either alone or in combination with probiotics or chemical allopathic veterinary drugs to treat these diseases [11]. In an economic analysis of those farms by Stonehouse et al. [9] organic producers reported lower expenses for veterinary costs, drugs or breeding compared to their conventional counterparts.

The majority of Ontario organic producers keep the Holstein breed; however, genetic selection for traits such as longevity, health, and grazing capability are emphasized more than production. Many farmers keep other purebred breeds (Brown Swiss or Jersey) or experiment with cross-breeding Holstein with Dutch Belted, Brown Swiss, Jersey, or Milking Shorthorn breeds in an effort to increase the animals' robustness and fitness. In organic herds, cross breeds and the use of a breeding bull are more common in herds with lower milk production than herds with higher milk production. The use of a breeding bull is also more common if minor or rare breeds are used because semen for artificial insemination is generally unavailable [7].

\section{Johne's Disease}

\subsection{Etiology and Epidemiology}

Johne's disease (JD) is a chronic, infectious gastrointestinal disease caused by Mycobacterium avium spp. paratuberculosis (MAP). MAP has been shown to infect a wide variety of domestic and wild ruminants such as cattle, sheep, goats, deer [13,14] and mouflons [13]. However, they have also been isolated from monogastric mammals such as rabbits [13,15,16] and hedgehogs [15], as well as from wild birds residing close to or on farm property [15].

MAP belong to the genus Mycobacterium and are, therefore, related to Mycobacterium tuberculosis and Mycobacterium bovis, which cause tuberculosis in humans and cattle, respectively. Significantly, MAP shares microbiological and pathogenic properties with those bacterial species. It is a very slow growing, acid-fast bacillus. Contrary to the other aforementioned species and its closer relative Mycobacterium avium spp. avium, MAP must be supplemented with the iron transport chemical mycobactin to grow. For this reason, it is an obligate intracellular organism [17].

As summarized by Tiwari et al. [18], disease progression can be divided into four phases. In the first silent phase, in animals less than 2 years of age, detection of infection with cost effective measures is not possible and clinical or subclinical effects are absent. In the subsequent second phase, or subclinical period, the infection can be detected by diagnostic tests (directly by fecal culture or PCR, or indirectly by serum or milk antibody) and can be associated with a drop in milk yield. In the third phase or clinical period, the animals show typical signs indicative of MAP infection. The clinical signs in cattle include chronic or intermittent diarrhea, gradual weight loss despite normal appetite, and loss in milk production. The infection can be detected by fecal culture/PCR or antibody ELISA. In the advanced clinical infection stage, affected animals, if not culled for this or other reasons, will develop hypoproteinemia, 
submandibular edema (bottle jaw) due to protein loss, and emaciation. Unless euthanized, animals reaching this phase eventually die due to cachexia.

Infected animals shed the bacteria mainly in the feces; however shedding via milk [19], semen [20-24], and saliva [25] have also been reported. Likely, the most common route of disease transmission is by ingestion of very small amounts of contaminated feces or milk early in a calf's life. The risk of a MAP-infected calf developing JD is particularly high for calves exposed at calving, where the calving area is highly contaminated [26]. For experimental infection, intravenous and subcutaneous inoculation has been used successfully [27]. It is unclear whether it is possible to infect cows with contaminated semen. The studies of Merkal et al. [28] and Owen and Thoen [29] showed positive antibody reaction, abortions, and likely antibody or MAP-positive calves when inoculating large concentrations of MAP into the uterus after artificial insemination. However, the test concentrations $\left(5 \times 10^{8} \mathrm{cfu}\right.$ MAP in $\left.5 \mathrm{~mL}\right)$ used by the authors are much higher than the concentrations usually found in semen $\left(10^{2}-10^{5} / \mathrm{mL}\right)[20]$. Recently, Whittington and Windsor [26] published a systematic review of intrauterine transmission from infected dams to the unborn calves. According to the authors, 39\% $(20 \%-60 \%)$ and $9 \%(6 \%-14 \%)$ of calves born to dams with clinical and subclinical JD, respectively, were JD-positive themselves.

Susceptibility to infection is highest when the animals are young and decreases as they age [26]. Therefore, most of the JD prevention efforts focus on calving and early calf rearing practices. Having cows calve in individual calving pens rather than group calving pens is associated with decreased odds of being a JD positive farm [30,31]. It is commonly recommended to remove the calf from the calving area as soon as possible $(<12 \mathrm{~h})$ after birth [32]. Other authors report access of calves less than 6 months of age to adult cows as being a major risk factor for JD transmission [33,34]. As summarized by Mitchell et al. [27] calves infected at $<3$ months of age were able to shed MAP beginning one month after the exposure, posing the risk of calf-to-calf transmission in group housing situations [35]. Furthermore, the source of colostrum and milk has been associated with JD transmission. Calves that receive colostrum from multiple cows rather than only from their own dam are at increased risk (odds ratio of 1.24) of being JD positive [36], and calves fed colostrum replacer are less likely to become infected with MAP compared to calves fed maternal colostrum at birth [37]. Similar associations hold true for the milk feeding period. Calves suckling a foster cow compared to receiving artificial milk replacer have increased odds of being JD positive [36].

It has been demonstrated that the odds of being JD-positive is greater for larger herds than for smaller herds $[30,38]$. Furthermore, farms that purchase stock from other farms are more likely to be positive than farms that do not purchase stock (closed herds) [30,31].

\subsection{Diagnostic Tests}

Typically, infected animals shed the bacteria before they show clinical signs. Numerous diagnostic tests have been developed and are applied in two ways. The first is to confirm the diagnosis of JD in the presence of clinical signs. The second is for early detection of subclinically infected individuals in an attempt to remove infected (i.e., exposed but not shedding) and infectious (i.e., exposed and shedding) animals from the herd to avoid further disease transmission and environmental contamination with MAP. In pathology, the gold standard test, the test that is considered the most accurate to diagnose the infection, is tissue culture of ileum tissue and adjacent lymph nodes with subsequent polymerase chain reaction 
(PCR) analysis to distinguish between MAP and other mycobacteria. The PCR uses the presence of the insertion segment IS900 and potentially the DNA sequences F57, ISMav2, and ISMap02 to identify MAP [39]. For in vivo diagnostics, fecal culture with confirmative PCR analysis is often considered the gold standard test. However, culturing MAP is very difficult, requiring multiple decontamination steps and a long incubation period of 4 to 6 months [39]. Direct fecal PCR, without prior culturing has been developed, but it is still not widely adopted [40]. Diagnostic tests based on antibodies against the bacteria have been established, with the most common one being Enzyme Linked Immuno Sorbent Assay (ELISA) applied to blood serum or milk. Estimates for sensitivity and specificity of common JD tests are presented in Table 1. The sensitivity of milk and serum ELISA, and direct fecal PCR, increases as cows increase the number of colony forming units (CFU) of MAP shed in the feces [40,41]. Furthermore, a high S:P ratio or high OD for serum and milk ELISA, respectively, is indicative of fecal shedding [41]. Due to the slow disease progression, the highest probability of testing positive is found in cows aging 2.5 to 4.5 and 2.5 to 5.5 years for ELISA and fecal culture, respectively [42]. However, the proportion of heifers $<2$ years old that started fecal shedding increases as the within-herd JD prevalence increases [43].

Table 1. Sensitivity and specificity of diagnostic tests for JD.

\begin{tabular}{|c|c|c|c|c|}
\hline Test & Reference Test & Sensitivity (\%) & Specificity (\%) & Reference \\
\hline \multirow{2}{*}{ Milk ELISA } & \multirow{2}{*}{ Fecal culture } & $61.1(48.9-72.4)$ & $94.7^{\mathrm{a}}$ & [41] \\
\hline & & 28.9 & 99.7 & [44] \\
\hline \multirow{10}{*}{ Serum ELISA } & \multirow{10}{*}{ Fecal culture } & $73.6(61.9-83.3)$ & $87.5^{\mathrm{a}}$ & [41] \\
\hline & & $16.7(4.5-28.8)$ & $97.1(96.0-98.1)$ & {$[45]^{\mathrm{c}}$} \\
\hline & & $13.9(2.6-25.2)$ & $95.9(94.6-97.2)$ & {$[45]^{\mathrm{c}}$} \\
\hline & & $27.8(13.1-42.4)$ & $90.1(88.2-92.0)$ & {$[45]^{\mathrm{c}}$} \\
\hline & & $31.3(20.6-43.8)$ & $97.8(94.5-99.4)$ & [40] \\
\hline & & 28.9 & 95.3 & {$[44]^{\mathrm{c}}$} \\
\hline & & 28.4 & 99.7 & {$[44]^{\mathrm{c}}$} \\
\hline & & 28.0 & 100.0 & {$[44]^{\mathrm{c}}$} \\
\hline & & 44.5 & 84.9 & {$[44]^{\mathrm{c}}$} \\
\hline & & 57 & 98.9 & {$[46]$} \\
\hline \multirow{3}{*}{ Serum ELISA } & \multirow{3}{*}{ Tissue culture } & $8.8(4.4-13.1)$ & $97.6(96.6-98.6)$ & {$[45]^{\mathrm{c}}$} \\
\hline & & $6.9(3.0-10.8)$ & $96.0(94.7-97.4)$ & {$[45]^{\mathrm{c}}$} \\
\hline & & $16.9(11.0-22.7)$ & $90.8(88.8-92.7)$ & {$[45]^{\mathrm{c}}$} \\
\hline Fecal culture & Repeated fecal culture & 38 & 100 & [47] \\
\hline Direct fecal PCR & Fecal culture & $70.2(57.7-80.7)$ & $85.3(79.3-90.1)$ & [40] \\
\hline \multirow{4}{*}{$\begin{array}{l}\text { Environmental } \\
\text { culture }^{\mathrm{d}}\end{array}$} & \multirow{2}{*}{ Individual fecal culture } & $71.4(49.2-86.5)$ & $98.6(94.8-99.6)$ & [48] \\
\hline & & 76.0 & $80.0^{\mathrm{a}}$ & [49] \\
\hline & Individual serum ELISA & 76.3 & $58.8^{\mathrm{a}}$ & [49] \\
\hline & Individual milk ELISA & 71.4 & $66.7^{\mathrm{a}}$ & [49] \\
\hline $\begin{array}{c}\text { Bulk tank milk } \\
\text { ELISA }^{\mathrm{d}}\end{array}$ & $\begin{array}{l}\text { Sensitivity: Individual fecal culture from Danish } \\
\text { herds; Specificity: bulk tank samples from } \\
\text { Norwegian herds considered to be negative }\end{array}$ & $97.1(83-100)^{b}$ & $83.3(74-90)^{b}$ & [50] \\
\hline
\end{tabular}

${ }^{a}$ Calculated based on data presented; ${ }^{b}$ Based on a cut-off (OD) of $0.02 ;{ }^{c}$ Different estimates of the same type of test by the same author indicate the use of different tests (e.g., different companies) or different test characteristics (e.g., different cut points); ${ }^{\mathrm{d}}$ Herd-level test. 
Nonetheless, there are still major deficits in diagnosing infected animals in vivo and many infectious animals may remain undetected. Therefore, most JD control programs focus on prevention of disease transmission rather than on test and cull strategies. A simulation study [51] showed that a JD control strategy involving management improvement in the calving and calf rearing area ( $<6$ months) will be more successful in reducing the JD prevalence than testing for JD and culling test positive animals only.

\subsection{Johne's Disease Prevalence and Control in Canada}

To decrease the prevalence and economic consequences of JD in Canadian dairy herds, the dairy industry (Dairy Farmers of Canada, Canadian Cattlemen's Association, and the Canadian Animal Health Coalition), governments, and veterinary schools collaboratively created the Canadian Johne's Disease Initiative (CJDI). The focus of this initiative is on education and awareness about JD, coordination of provincial working groups, and coordination and facilitation of JD research activities. The JD programs are administered provincially and most provinces have established a JD control program [52]. The duration of the programs, the budgets, as well as participation differ greatly by province and region (Table 2). It is noteworthy that the majority $(88 \%)$ of the Ontario program was funded by the dairy industry rather than the public.

Table 2. Description of Johne's disease control programs in Canadian provinces and regions [53].

\begin{tabular}{lccccc}
\hline Region/Province & Duration & Budget & $\begin{array}{c}\text { Main } \\
\text { Sponsoring Body }\end{array}$ & $\begin{array}{c}\text { Number of Farms } \\
\text { Participating (\%) }\end{array}$ & $\begin{array}{c}\text { Number of Trained } \\
\text { Dairy Veterinarians (\%) }\end{array}$ \\
\hline Atlantic Canada a $^{\text {a }}$ & $2011-2014$ & $1,000,000$ & Public & $459(69)$ & $49(60)$ \\
Quebec & $2007-2014$ & $1,600,000$ & Public & $1362(22)$ & $161(47)$ \\
Ontario & $2010-2013$ & $2,440,000$ & Industry & $2339(58)$ & $246(>95)$ \\
Manitoba & $2010-2011$ & 100,000 & Public & $200(57) \mathrm{b}$ & $20^{\mathrm{b}}$ \\
Saskatchewan & $2012-2013$ & 125,000 & Public & $20(12)$ & $10^{\mathrm{b}}$ \\
Alberta & $2010-2013$ & $1,040,000$ & Public & $350(61)$ & $78(95)$ \\
British Columbia & $2009-2012$ & 250,000 & Public & $30(6)$ & $11(50)$ \\
Canada & $2007-2014$ & $6,600,000$ & Public & $4759(>35)$ & $575(>60)$ \\
\hline
\end{tabular}

${ }^{a}$ New Brunswick, Nova Scotia, Prince Edward Island; ${ }^{b}$ approximate.

When delivering the program at the farm level, trained veterinarians gather the herd history and evaluate the animal management practices using a standardized risk assessment instrument, and then make recommendations regarding herd testing. The herd owner and the veterinarian decide on a plan to implement best management practices for JD control. The tool used for this process is a Risk Assessment and Management Plan (RAMP). While the RAMP was adopted more uniformly across the provincial programs, the testing methods differ substantially. Some programs utilize environmental testing alone (Alberta Johne's Disease Initiative) or in combination with individual animal testing (Atlantic Johne's Disease Initiative). Other programs use only individual testing (Ontario Johne's Disease Education and Management Assistance Program, Quebec Voluntary Paratuberculosis Prevention and Control Program). The tests include fecal culture and fecal PCR, as well as milk and serum ELISA [52]. Prevalence estimates for the provinces are presented in Table 3. 
Table 3. Johne's disease herd-level prevalence in Canadian provinces.

\begin{tabular}{lccc}
\hline \multicolumn{1}{c}{ Province } & Test & Herd Level Prevalence (\%) & Reference \\
\hline New Brunswick & Serum ELISA & $43.3^{\mathrm{a}}(24.5-62.2)$ & {$[54]$} \\
Nova Scotia & Serum ELISA & $53.3^{\mathrm{a}}(34.4-72.2)$ & {$[54]$} \\
Prince Edward Island & Serum ELISA & $33.3^{\mathrm{a}}(15.4-51.2)$ & {$[54]$} \\
Atlantic provinces $^{\mathrm{d}}$ & ${ }^{\text {Environmental culture }}$ & 20 & {$[55]^{\mathrm{c}}$} \\
\hline Quebec $^{*}$ & Serum ELISA & 42.5 & {$[56]^{\mathrm{c}}$} \\
\hline \multirow{2}{*}{ Ontario } & Serum ELISA & $58^{\mathrm{a}}(44-72)$ & {$[57]$} \\
& Milk ELISA & $34^{\mathrm{a}}(21-47)$ & {$[57]$} \\
Manitoba & Milk or Serum ELISA & 26 & {$[58]^{\mathrm{c}}$} \\
\hline Saskatchewan & Serum ELISA & $68.4^{\mathrm{a}}(52.5-84.2)$ & {$[59]$} \\
\hline \multirow{3}{*}{ Alberta } & Serum ELISA & $43.3^{\mathrm{a}}(27.4-59.3)$ & {$[60]$} \\
& Serum ELISA & $40.0 \pm 13.66^{\mathrm{b}}$ & {$[61]$} \\
& Serum ELISA & $70.2^{\mathrm{a}}(53.7-86.6)$ & {$[62]$} \\
\hline
\end{tabular}

${ }^{a}$ Herd considered positive if 1 or more cows tested positive; ${ }^{b}$ Herd considered positive if 2 or more cows tested positive; ' Provincial or regional Johne's disease program website; ${ }^{d}$ Atlantic provinces include Nova Scotia, New Brunswick, Prince Edward Island, and Newfoundland and Labrador.

\section{Johne's Disease Prevalence on Organic Dairy Farms}

Very few researchers have investigated JD prevalence on organic dairy farms. Three of them [64-66] are published as conference proceedings that are usually limited by space provided and are therefore lacking in detail.

One report from The Netherlands states that the JD prevalence on organic farms was similar to the prevalence on conventional farms [64]. In 2003, the authors collected blood from almost 3700 animals that were older than 36 months from 76 organic farms and tested these samples with a serum ELISA. Using a concurrent risk assessment, they reported higher risk scores (higher risk for disease transmission) for the biosecurity, calving, and pre- and post-weaned calf management areas on organic farms compared to measures from previous studies. The authors reported an individual serum prevalence of $1.2 \%$ and $1.7 \%$, and a herd level prevalence of $36 \%$ and $39 \%$ on organic and conventional farms, respectively. While they found more high risk management practices on organic farms, they concluded that there was no difference in serum ELISA prevalence [64]. The study does not comment on herd size in their report and it is therefore difficult to put the findings into perspective.

A survey from Quebec, Canada, studied a regionally stratified random sample of 60 organic dairy herds [65]. They conducted a serum ELISA on 30 cows in each of those herds. The authors found an individual serum prevalence of $0.8 \%$ (CI: $0.0 \%-1.3 \%$ ) and a herd level prevalence of $20.3 \%$ (CI: $10.0 \%-32.8 \%$ ). It was concluded that MAP was probably less of an important disease on organic than on conventional farms based on a comparison with historical estimates of JD prevalence in Quebec [65]. In this study, it is unclear how the herd size and other characteristics of the sample herds compare to those of conventional Quebec farms. It is also unclear how the historical estimates were derived (e.g., fecal culture, milk ELISA, or environmental sample).

A concurrent study on organic and conventional dairy farms in Minnesota, USA, used environmental samples to determine MAP infection status [66]. The author reported a lower MAP herd-level prevalence 
on organic and small ( $<200$ cows) conventional dairy farms compared to large ( $\geq 200$ cows) conventional dairy farms (43\%, 47\%, and $92 \%$, respectively).

Similarly, Zwald et al. [67] stated that JD was more commonly reported by producers on conventional than organic dairies based on a management questionnaire of a sample of farms from Michigan, Minnesota, New York, and Wisconsin, USA. However, the conventional herds were larger than the organic herds in this study. Commonly, larger herds have a higher JD prevalence than smaller herds [30,38]. Therefore, comparisons cannot easily be made without adjustments for herd size.

Despite their limitations, these studies give an indication of how JD prevalence compares between organic and conventional farms. However, they are of limited value in understanding the relationship between organic farming and JD. In the following sections, a comparison between organic practices and Johne's prevention practices is presented. Where appropriate, links to additional infectious diseases are given to further support critical evaluation of organic management practices.

\section{Association between Johne's Disease and Organic Dairy Farming}

\subsection{Farm Structure}

During the ongoing process of intensification of dairy farming and agriculture as a whole, dairy farms are required to grow or, if they are unable to do so, increase farm income by other means to avoid exiting the industry. While there are many other reasons why producers convert to organic farming, some smaller farms might see an opportunity to avoid the consolidation process and increase farm income by converting to organic milk production. More recent reports demonstrate that organic farms tend to be smaller than conventional farms $[7,8,67,68]$ (Figure 2). Small farms have been shown to have decreased odds of being JD positive [30,38] and, thus, smaller organic farms might have a reduced JD herd level prevalence compared to larger conventional farms.

Figure 2. Average herd size in organic and conventional Canadian dairy herds (data from [7-9,69]).

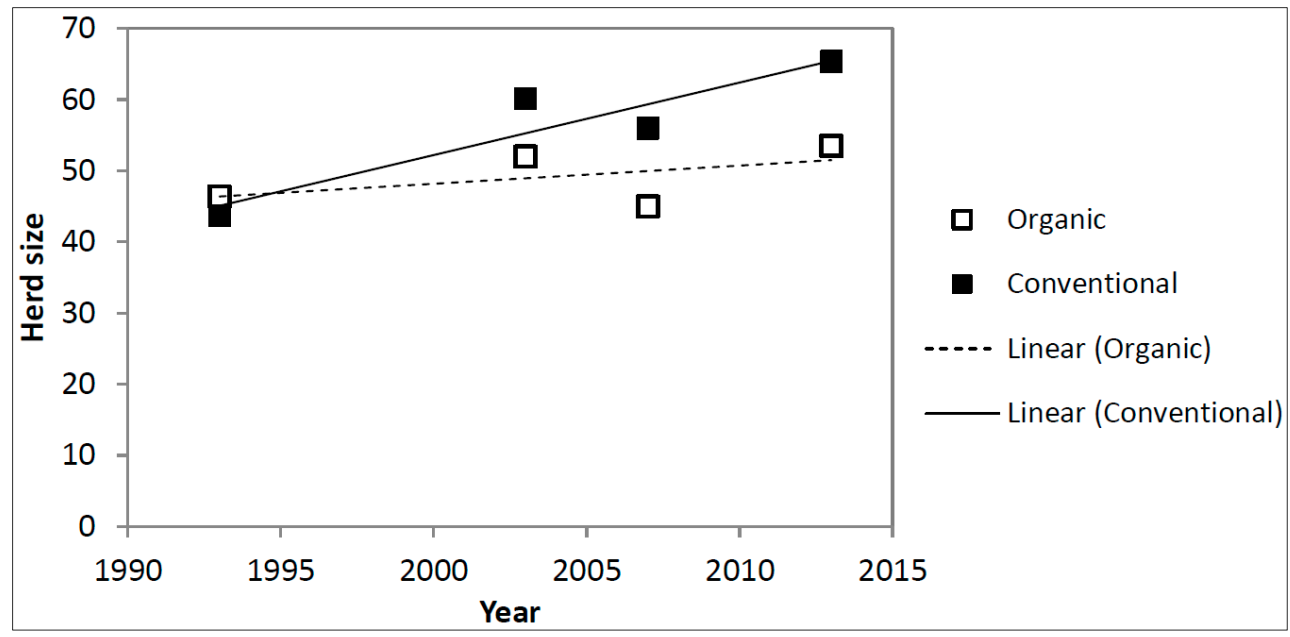

On the other hand, compared to larger specialized farms (e.g., only milk production), smaller organic farms might still practice mixed farming (e.g., presence of other livestock species) for commercial purposes or own use. This might increase the risk of transmission of diseases that are shared among other species and dairy cattle. A clear separation between animals of different species is not always possible 
or desirable. For example, some farmers might let chickens follow cows on pasture and pick through the dung pats to search for food (e.g., fly maggots and larvae). For parasite control, it is a common recommendation to rotate pasture use among different species (e.g., horses and cattle). One might speculate that species that could harbor MAP but might not get tested for MAP infection could routinely come in direct or indirect contact with the cattle and could, therefore, transmit MAP to them.

A common claim in the organic industry is that because of a reduced milk yield, regular pasture access and higher forage content in the overall ration, as well as breeding for longevity and fitness, organically raised animals have a lower disease incidence and greater longevity than conventionally raised dairy animals. This is the foundation for the belief that organic farms have older cows than conventional farms. Stiglbauer et al. [70] reported an average lactation number of 2.6 and 2.3 lactations, and an average proportion of 1 st lactation animals of $31.6 \%$ and $37.3 \%$ on organic and conventional farms, respectively. Similarly, Hardeng and Edge [71] reported a significant difference between the average lactation number of 2.97 on organic compared to 2.35 on conventional Norwegian dairy farms. Older cows are thought to be more profitable than younger cows because of increasing milk yield in higher lactations. However, older cows are also associated with an increase in health problems such as clinical mastitis, elevated SCC, milk fever, ketosis or JD [71,72]. JD is also more likely to be detected in older animals [73]. According to Tiwari et al. [31], the odds of a farm being JD negative decreases with increasing mean lactation number $(\mathrm{OR}=0.2,95 \% \mathrm{CI}: 0.1-0.8)$. Therefore, a potentially increased JD prevalence on organic farms might be caused by an increased transmission of MAP by older cows and the greater likelihood of detection of their infection in these older animals. On the other hand it is unclear whether those biologically small differences will really lead to differences in disease prevalence or an increased risk of disease transmission.

\subsection{Crop Management}

Organic farmers try to maintain or increase soil health and fertility through the use of long crop rotations, cover crops, and utilization of manure and compost [11]. Organic farms aim to preserve or increase organic matter in the soil which helps to retain water and nutrients in the soil and harbors microorganisms beneficial for plant health and performance [12]. However, increasing soil organic matter has also been associated with increased survival of ovine MAP on pastures in Australia [74]. This could indicate an indirectly increased risk for MAP survival and transmission on organic dairy farms, but it remains unclear how bovine MAP behaves in soils with different organic content. Besides soil organic matter, other nutrients such as $\mathrm{K}, \mathrm{N}$ and $\mathrm{P}$ might change under organic management [8]. The effect of those changes on the survival of MAP on pastures or fields is also unclear. Furthermore, while the detection of viable MAP is greatly reduced in thermophilic compost compared to liquid manure, MAP DNA can be detected in compost up to 56 days and liquid manure up to 175 days [75]. Composting has also been shown to be ineffective for decontamination of carcasses infected with MAP, even after 250 days [76]. This indicates that proper thermophilic composting could reduce the danger of recycling MAP on the farm, but only if contaminated carcasses are disposed otherwise. 


\subsection{Nutrition}

Grazing is a requirement of organic dairy production [2]. Sun exposure during grazing could, through increased vitamin D production in the skin and therefore calcium mobilization, help to reduce milk fever at calving. However, besides its importance in the calcium homeostasis, vitamin D plays a crucial role in immune functions and vitamin D deficiency has been associated with disease susceptibility [77]. It has recently been shown that the vitamin D concentration in cows with positive JD serum ELISA status is lower than in cows with a negative status [78]. Although the aforementioned authors do not indicate a causal relationship, research needs to be done to determine if pasturing cattle might be a strategy to suppress spread of MAP infection and clinical signs of JD through the mechanism of increased vitamin D availability.

Appropriate pasture management is complex and the farmer needs to assure that the animals have access to feed and water, that dry cows have ideal body condition at calving, that milking cows and young stock have access to enough high-quality feed to sustain milk production or growth, respectively, that the parasite burden is kept at a minimum, and that the animals have shelter. Farmers also need to assure that the pastures are properly fenced so that the livestock are kept in the pastures, and predators and other wildlife that might share pathogens are kept out of the pastures. For example, wild ruminants and other wild non-ruminants (e.g., rabbits) can harbor and shed MAP [13,15,16]. The presence of deer on the farm has been associated with increased odds of being JD positive [79]. However, according to a study by Zwald et al. [67], there is no difference in farmer reported contact rates with other farmed or wild animals between conventional and organic dairy farms. Nevertheless, it remains unclear how well rabbits or deer can be kept off the pastures at any time during the year. It is also unknown how long MAP shed by those wild animals can survive on the pasture and if this poses a significant source of new infection for organic or pastured dairy cattle.

To sustain low parasite infestation in the herd and achieve sufficient, high-quality feed intake, farmers rotate their pastures regularly. Only a few researchers have investigated the survival of MAP on pasture; it was found to survive up to 4 months [13] in the open and up to 55 weeks in the fully shaded areas [80]. However, one can assume that a significant decontamination of the pastures is achieved within a few weeks. It was suggested that grazing with unsusceptible species or cutting could hasten decontamination due to decrease of shaded soil areas [80]. As common pasture rotations return cattle to potentially contaminated fields within 4 to 6 weeks, it is unlikely that pasture rotation alone will provide an effective measure against JD transmission. However, it is also doubtful that this management practice will increase JD transmission except if calves or heifers are rotated after adult cows as is commonly recommended for parasite control [81].

Zwald et al. [67] and Kijlstra [64] reported that organic farms use surface water more frequently than conventional farms as drinking water for livestock. This might pose the risk of spread of diseases that are transmitted by organisms that survive in the water or in the moisture around the water accesses, such as internal parasites (e.g., liver fluke). Furthermore, as previously mentioned, MAP can survive up to 48 and 36 weeks in dam water or shaded and semi-exposed areas, respectively. The survival in the sediment was 12 to 24 weeks longer than in the water column. In this study, survival of MAP in soil and fecal material in the shade was only 12 weeks [82]. However, it is unclear, how those experimental 
results translate to MAP exposure from ponds and streams where cows have access. It is also unknown if Canadian organic dairy farmers use surface water as drinking water for their livestock.

In the wintertime, cows on organic farms are required to get regular outdoor access [2] often provided through a winter paddock or exercise lot. Research from the USA showed that the utilization of an exercise lot was associated with a three-fold increase in the odds of a herd being JD ELISA positive [83]. Although the definition of an exercise lot might vary from farm to farm, this indicates that the management (e.g., cow density and cleanliness) of the exercise lot is insufficient on the majority of farms to prevent further spread of the disease.

\subsection{Calving and Dairy Heifer Management}

For JD control it is recommended to let cows calve in a clean calving area, separate from other cows rather than in group calving areas [32]. Organic farms have been reported to less often have a separate maternity area than conventional farms $[64,67]$ and might therefore be at an increased risk of transmitting JD. Additionally, many organic farms let cows calve on pasture, where the animal density may be lower, but where access to other cows is possible. Furthermore, calves born on pasture would be more likely to suckle the first colostrum rather than be bottle or tube fed. To date, no research has been done to investigate the risk of JD transmission when cows calve on pasture.

According to the COS, calves have to be fed with natural milk within the first day of life [2]. Nursing, in terms of using foster cows or just the own dam, is not a requirement in organic farming in Canada; however, it may be practiced among organic producers. In a study from The Netherlands, organic dairy producers were reported to leave the calves with the dam more often and feed artificial milk replacer less often [64]. In conventional dairy herds, it is generally recommended that calves are removed from the dam quickly after calving and that cleanly milked colostrum from the calf's own dam, a JD test negative cow, or artificial colostrum replacer is given to the calf in sufficient amount soon after birth [32]. Therefore, farms that let the calves suckle the dam could have an increased risk of JD transmission. On the other hand, calves fed colostrum from multiple cows and not just their own dam, are reported to have an odds ratio of 1.2 of testing JD positive compared to calves that received colostrum from their own dam only [36]. It remains unclear if the risk might be lower when the calf is suckling a single test negative cow only rather than receiving a mixture of colostrum from recently calved cows. In the latter situation, an infected but still undiagnosed cow might be shedding MAP and could potentially infect multiple calves in a birth cohort receiving her colostrum or milk, whereas in the former situation only one calf or few calves get infected. In addition, if a nurse cow gets diagnosed with JD later, her offspring or the calve(s) that received her milk and was exposed to her manure can easily be identified and removed from the herd if appropriate records exist on the farm. Nevertheless, in the study by Nielsen et al. [36], calves that suckled a foster cow had 2.0 times the odds of testing positive compared to calves fed milk replacer. This indicates that the management of foster cows might be still insufficient to prevent JD transmission.

Feeding high SCC or non-saleable milk is more common on organic than conventional farms in The Netherlands [64]. This might be due to the imposition of longer withdrawal times for therapeutic treatments on organic compared to conventional farms. Although this practice is prohibited by the COS [2], after the infection has cleared, farmers might use milk from treated cows to feed the calves and 
save saleable milk to increase their income. This practice could increase JD transmission to the calves as there seems to be a strong positive association between JD milk ELISA antibodies and high SCC [84] and farmers would be more likely to feed high risk milk to susceptible calves. Tavornpanich et al. [85] reported that feeding non-saleable milk was a risk factor for having a high JD ELISA prevalence in the herd.

According to a study by Zwald et al. [67], organic farms group feed pre-weaned calves more often than conventional farms. In Canada, organic farms that do not use nurse cows can house their calves either together or individually in hutches with access to a little yard until three months of age, provided they are not tethered, and the calves can see, hear and smell other calves. After weaning, calves have to be housed together [2]. This increased contact between calves is likely positive for the development of the calves' social skills [86] but might pose a risk for infectious disease transmission among calves. For JD control, it is recommended to isolate calves from each other until 30 days of age [32]. Mitchell et al. [27] showed that most MAP infected calves enter an early shedding period in which they can transmit the bacteria to other calves [35]. Group housing replacement heifers might therefore increase the risk for JD transmission on organic and conventional dairy farms. In contrast, Marcé et al. [33] demonstrated in their modelling study that group housing of calves did not influence MAP transmission in a herd.

Depending on the season, replacement calves that are greater than nine months old must have pasture access [2]. This will again pose an increased risk for parasite infestation and suboptimal nutrition during that time. Heifers that are co-housed or rotated with adult cows might also have an increased risk of getting infected with MAP. In a meta-analysis, it was specified that about $50 \%$ of heifers inoculated at 6 to 12 months of age develop lesions indicative of bovine JD [26], showing that infection at those ages still occurs. According to Kijlstra [64], Dutch organic farmers keep their calves more often than conventional farms on pastures that have been used by adult cattle or goats, or that have been fertilized with cattle or goat manure earlier that season. On the other hand, Marcé et al. [33] showed that the longer contact between calves and cows could be delayed, the more the prevalence can be decreased over time in a JD control program. Therefore, co-housing or rotating calves after cows might make JD control on organic farms more difficult than on conventional, non-grazing farms.

\subsection{Veterinary Treatments}

As preventive or metaphylactic treatment of animals is commonly banned in organic farming, it becomes challenging to manage parasite burden in pastured animals. Specific parasiticides are allowed in cases where an individual animal has a proven infestation with parasites and is unable to cope with this situation on its own [2]. Monensin is an example of a coccidiostatic and growth promoting medication and is commonly fed on conventional farms, but is not allowed in organic production. Feeding monensin has been shown to marginally reduce the amount of MAP shed in a clinical trial [87] but was also associated with reduced odds of testing milk ELISA positive in an observational study [88]. In a comparative study by Zwald et al. [67], 22\% of conventional herds used monensin as a feed additive for pre-weaned and weaned heifers whereas none of the organic herds did. As a result, organic farms might have an increased prevalence of cows testing positive for JD. 
In the case where an animal gets sick, organic farming regulations prefer alternative treatment options (homeopathics, herbal medicine) over chemical allopathic veterinary drugs [2]. In western Ontario, Canada, homeopathic remedies are commonly used either in conjunction with chemical allopathic veterinary drugs or alone [11]. Moreover, the use of homeopathy is widely disseminated $(10 \%-42 \%$ of farms) among organic farmers for mastitis therapy as reported from three European countries [89]. Multiple problems arise from the use of alternative treatments. In some cases, the use of alternative treatments is not in agreement with national drug and food safety regulations as most alternative treatment options are not licensed for veterinary usage for the desired indication. Therefore, with the exception of homeopathic remedies, it would be required that veterinarians prescribe them if they are to be used in dairy cattle. However, for the majority of alternative treatment options, clinical studies on efficacy, safety or withdrawal times are non-existent [90] and consequently, practitioners might hesitate or are simply unable to legally prescribe them all together.

Veterinarians' lack of support for those alternative treatments might force the farmer to seek advice from other health professionals, lay or sales people or other farmers. It has been reported that veterinarians are not utilized as much on organic as on conventional farms [9]. Organic farms have been reported to have fewer veterinary visits per year, fewer routine veterinary visits, are less likely to call for emergencies, and fewer farms utilize preventive vaccination, consult with a nutritionist, or enroll in regular milk recording compared to conventional farms [91]. However, it should be noted that veterinary usage is more associated to intensity of management rather than organic or conventional status [91]. Organic farmers that do not regularly utilize those external inputs might also be less likely to participate in a disease prevention program (e.g., JD control) led by veterinarians. In the comparison of participants and non-participants in the voluntary Ontario, Canada, JD program, more progressive farmers with better management were more likely to participate in the program. Among the reasons cited for non-participation was the unwillingness to pay the veterinarian to do the risk assessment and a farm policy to not participate in any formal programs [92]. Organic farmers might, therefore, be less likely to participate in a JD control program or seek advice for JD control from their veterinarians.

Furthermore, an organic farmer might be tempted to cull a sick animal early to avoid further disease transmission, high veterinary costs, or long withdrawal times for veterinary treatments. Thus, organic farmers tend to have fewer consultations with external dairy professionals which might pose the risk that diseases such as mastitis or JD arise but remain undetected for a longer time. On the other hand, culling, rather than trying to treat diseased animals, potentially reduces environmental contamination with disease pathogens. In a modeling study, decreasing the mean time clinical JD cows spent on the farm, decreased the JD prevalence over time [33].

Another favorable aspect of early culling of diseased animals is the selection for disease resistance. If through early culling diseased animals are less likely to reproduce, healthy animals will have a reproductive advantage over sick/susceptible animals and their genes would subsequently have a higher abundance within the population. This would potentially lead to offspring with higher disease resistance and reduced disease incidence over time. Thompson-Crispi et al. [93] showed that decreased disease incidence was associated with high adaptive immune response measured by a standardized test in an US Holstein dairy herd. Additionally, Pinedo et al. [94] demonstrated that increasing cellular immune response was associated with reduced odds of serum ELISA positivity. However, a Dutch modelling study by van Hulzen et al. [95] showed that responses to JD ELISA-negative selection alone are 
relatively small, potentially requiring centuries for JD to be eliminated from the dairy herd using this technique. To date, no research has investigated the distribution of high immune responders in organic versus conventional dairy farms and it is unknown if the culling strategy and disease selection on organic farms will lead to a higher prevalence of high immune responders and, therefore, reduced JD prevalence.

\subsection{Biosecurity}

As mentioned above, organic farmers tend to have fewer consultations with external dairy professionals. With this strategy, organic farmers might try to limit the number of professionals with regular animal contact entering the farm. This might be a measure of biosecurity to avoid transmission of highly infectious diseases such as Bovine Viral Diarrhea (BVD), Infectious Bovine Rhinotracheitis (IBR), Bovine Respiratory Disease (BRD), or winter dysentery, again, because treatment options are very limited. Similarly, as a measure of biosecurity and due to problems with sourcing certified organic inputs, organic farmers tend to raise their own replacement animals $[9,70]$ and limit purchase of expensive external inputs such as feed $[9,67]$. It has been shown that farms that regularly purchase animals have a higher risk of being JD positive and of having higher JD seroprevalence than herds that stay closed $[30,31,96]$. Therefore, organic farms might be less likely to introduce the disease into the herd by external inputs. Contrarily, Kijlstra [64] reported that a sample of Dutch organic farms had less stringent biosecurity measures than conventional farms, such that they less often provide separate farm clothes for visitors, more often purchase animals from farms with unknown paratuberculosis status, and more often use manure from other farms compared to conventional farms. To date, it is unknown how those biosecurity measures on Canadian organic and conventional farms compare to each other.

\subsection{Breeding Strategy}

The limitation to purchasing external breeding stock does not always extend to the breeding bull. Organic regulations in Canada state a preference for natural breeding but allow for artificial insemination [2]. As stated above, organic farms more often keep a breeding bull on the farm and this bull is sometimes purchased from other farmers to reduce the risk of inbreeding. If organically-raised bulls are unavailable, conventionally-raised bulls can be used instead [2]. Therefore, bulls could be purchased from larger conventional herds or the auction market. Larger farms are more likely to have a positive JD herd status than smaller herds [30,38] and herd additions from those sources might cause a higher risk of introducing the disease into the herd.

Besides the source of the addition, a breeding bull poses a different risk for disease transmission that is often ignored. After raising or purchasing a breeding bull, he is often co-housed (on pasture or in the barn) with dairy replacement heifers to avoid the extra work of watching for heat and artificial insemination. In a large US based study, $66 \%$ of organic farms compared to only $44 \%$ of non-grazing conventional farms were reported to use natural service for some or all replacement heifers [70]. During that period, the heifers are usually 10 to 20 months old and still marginally susceptible to the oral infection with MAP [26,27].

However, of particular concern are the previously mentioned reports about additional routes of disease transmission associated with the bull. Between 1970 and 2010 researchers have demonstrated that infected breeding bulls can shed MAP not only in the feces but also in the semen [20-24], while 
still maintaining acceptable semen quality. They shed the bacteria at low to moderate levels $\left(10^{2}-10^{5} / \mathrm{mL}\right)$ and shedding might be intermittent [20]. MAP has also been found in male reproductive organs at pathological examination [20,97].

On the other end of a potential venereal transmission route, Merkal et al. [28] and Owen and Thoen [29] showed that infecting heifers and cows intrauterine with large doses of MAP is possible, leading to abortions, positive antibody reactions in inoculated animals, prolonged recovery of the organism from the uterus, and likely antibody or MAP positive calves. Although it has not been proven that breeding bulls infect cows or heifers through mating, it could be suspected that bulls could play a role in transmission of JD and that organic farms are therefore at an increased risk of introducing and transmitting JD in the herd.

Canadian organic farming regulations also recommend utilizing breeds or lines that are adapted to the specific environmental conditions [2]. The predominant breed on organic farms is Holstein; however, organic farms more often use cross breeds [91] or other purebred breeds than conventional farms. Rozzi et al. [7] reported that the use of minor or heritage breeds was associated with increased usage of breeding bulls. In Canada, Channel Islands breeds (e.g., Jersey, Guernsey) have been shown to have increased odds of being JD ELISA positive [72]. Lombard et al. [98] showed that non-Holstein breeds are more likely to test positive using serum or milk ELISA. Therefore, when trading with or breeding those breeds, organic farmers may be more likely to introduce and spread JD on their farm.

\section{Knowledge Gaps}

Most of the aforementioned potential associations between JD and organic farming are based on the review of the broader literature and not on empirical studies on organic dairy farms. Therefore, there are many knowledge gaps and research needs. Addressing those needs will not only benefit the organic dairy farming community, but will also help smaller conventional dairy farms that employ similar management practices, to reduce the risk for JD transmission.

To more clearly understand the relationship between organic farming and MAP transmission, a concurrent comparison between the organic and conventional farming systems in terms of JD prevalence and risk factors is necessary, while at the same time accounting for herd size and farming intensity as major confounders. This will rule out biases introduced by using historical data for comparison or differences in herd size and intensity that might impose differences in management practices.

The relationship between organic dairy farmers and veterinarians seems to be challenged by differing views and requirements of each profession imposed by organic requirements. Researchers and educators need to be able to understand and make targeted recommendations and adjustments to improve this relationship. Only a strong and trustful relationship will facilitate the delivery of animal health and welfare programs among the organic livestock industry and results in improvement of animal wellbeing and food safety for the consumer.

As shown above, a number of researchers have investigated the prevalence of MAP in reproductive organs of infected bulls. It is unclear whether a breeding bull on dairy farms poses a major risk for JD transmission. A survey of breeding bulls on commercial organic and conventional dairy farms would help to determine the prevalence of MAP infected individuals. Strain typing infected offspring of JD-positive bulls might further help to demonstrate an association. Challenge trials utilizing similar 
MAP concentrations found in semen would be needed to show if intrauterine infection through mating by infected bulls is possible.

As pasturing is a requirement under organic regulations, farmers are unlikely to change this management practice. It has been demonstrated that MAP can survive on pasture for very long time and that MAP can be shed by wild animals that also may reside on pastures. Research needs to be done to determine the extent of JD transmission on pasture and how to reduce it. Further, it needs to be investigated whether calving on pasture poses an increased risk compared to calving in the barn.

Another practice that farmers are unlikely to change is letting calves nurse the cows. It is therefore first necessary to determine the risk of JD transmission by suckling versus other feeding practices (e.g., group feeding milk to calves). Secondly, it needs to be investigated how the disease transmission risk could be decreased (e.g., only use test negative cows) to benefit from the positive aspects of nursing.

\section{Conclusions}

Farming practices and regulations might directly or indirectly alter the risk for JD transmission on Canadian organic dairy farms. Ultimately, estimates of how much each of those factors will alter JD transmission risk on organic farms are unavailable and predictions about overall change in herd-level and within-herd prevalence are impossible. Farmers engaging in organic practices might need to critically review their management regarding possibilities of infectious disease transmission. They may also need to test the herd for JD more frequently and pay special attention to hygiene and biosecurity measures. More research is needed to address major knowledge gaps. Closing those gaps will not only benefit organic farms, but also smaller conventional farms that employ management practices similar to organic farms.

\section{Acknowledgments}

This research was funded by the Ontario Ministry of Agriculture and Food (OMAF)-University of Guelph research partnership.

\section{Author Contributions}

Laura Pieper, Ulrike Sorge, Ann Godkin, Trevor DeVries, Kerry Lissemore, and David Kelton collaboratively designed this review. Laura Pieper wrote the paper and Ulrike Sorge, Ann Godkin, Trevor DeVries, Kerry Lissemore, and David Kelton edited the manuscript.

\section{Conflicts of Interest}

The authors declare no conflict of interest.

\section{References}

1. Agriculture and Agri-Food Canada (AAFC). Organic dairy industry in Canada. Available online: http://www.dairyinfo.gc.ca/pdf/organic_profile_eng.pdf (accessed on 5 January 2014).

2. Government of Canada. CAN/CGSB-32.310-2006 Organic Production Systems-General Principles and Management Standards; Government of Canada: Ottawa, ON, Canada, 2006. 
3. Hill, S.B.; MacRae, R.J. Organic farming in Canada. Agric. Ecosyst. Environ. 1992, 39, 71-84.

4. Government of Canada. CAN/CGSB-32.311-2006 Organic Production Systems-Permitted Substances Lists; Government of Canada: Ottawa, ON, Canada, 2006.

5. Government of Canada. Organic Products Regulations, 2009 (SOR/2009-176); Government of Canada: Ottawa, ON, Canada, 2009.

6. Agriculture and Agri-Food Canada (AAFC). Certified organic production statistics for Canada. Available online: http://www.agr.gc.ca/eng/industry-markets-and-trade/statistics-and-marketinformation/by-product-sector/organic-products/organic-production-canadian-industry/certifiedorganic-production-statistics-for-canada-2009/?id=1312385802597\#a3 (accessed on 15 January 2014).

7. Rozzi, P.; Miglior, F.; Hand, K.J. A total merit selection index for Ontario organic dairy farmers. J. Dairy Sci. 2007, 90, 1584-1593.

8. Roberts, C.J.; Martin, R.C.; Juurlink, S.D.; Lynch, D.H.; Voroney, R.P. Nutrient budgets of Ontario organic dairy farms. Can. J. Soil Sci. 2008, 88, 107-114.

9. Stonehouse, D.P.; Clark, E.A.; Ogini, Y.A. Organic and conventional dairy farm comparisons in Ontario, Canada. Biol. Agric. Hortic. 2001, 19, 115-125.

10. Ogini, Y.O.; Clark, A.; Stonehouse, D.P. Comparison of organic and conventional dairy farms in Ontario. Am. J. Altern. Agric. 1999, 14, 122-128.

11. Sholubi, Y.O.; Stonehouse, D.P.; Clark, E.A. Profile of organic dairy farming in Ontario. Am. J. Altern. Agric. 1997, 12, 133.

12. Lynch, D. Environmental impacts of organic agriculture: A Canadian perspective. Can. J. Plant Sci. 2009, 89, 621-628.

13. Machackova, M.; Svastova, P.; Lamka, J.; Parmova, I.; Liska, V.; Smolik, J.; Fischer, O.A.; Pavlik, I. Paratuberculosis in farmed and free-living wild ruminants in the Czech Republic (1999-2001). Vet. Microbiol. 2004, 101, 225-234.

14. Nebbia, P.; Robino, P.; Ferroglio, E.; Rossi, L.; Meneguz, G.; Rosati, S. Paratuberculosis in Red Deer (Cervus elaphus hippelaphus) in the Western Alps. Vet. Res. Commun. 2000, 24, 435-443.

15. Nugent, G.; Whitford, E.J.; Hunnam, J.C.; Wilson, P.R.; Cross, M.L.; de Lisle, G.W. Mycobacterium avium subsp. paratuberculosis infection in wildlife on three deer farms with a history of Johne's disease. N. Zeal. Vet. J. 2011, 59, 293-298.

16. Judge, J.; Kyriazakis, I.; Greig, A.; Allcroft, D.J.; Hutchings, M.R. Clustering of Mycobacterium avium subsp. paratuberculosis in rabbits and the environment: How hot is a hot spot? Appl. Environ. Microbiol. 2005, 71, 6033-6038.

17. Rolle, M.; Mayr, A. Medical Microbiology and Epidemiology (Medizinische Mikrobiologie, Infektions- und Seuchenlehre); Enke: Stuttgart, Germany, 2007; Volume 8.

18. Tiwari, A.; VanLeeuwen, J.A.; McKenna, S.L.B.; Keefe, G.P.; Barkema, H.W. Johne's disease in Canada Part I: Clinical symptoms, pathophysiology, diagnosis, and prevalence in dairy herds. Can. Vet. J. 2006, 47, 874-882.

19. Streeter, R.N.; Hoffsis, G.F.; Bech-Nielsen, S.; Shulaw, W.P.; Rings, D.M. Isolation of Mycobacterium paratuberculosis from colostrum and milk of subclinically infected cows. Am. J. Vet. Res. 1995, 56, 1322-1324. 
20. Khol, J.L.J.; Kralik, P.P.; Slana, I.I.; Beran, V.V.; Aurich, C.C.; Baumgartner, W.W.; Pavlik, I.I. Consecutive excretion of Mycobacterium avium subspecies paratuberculosis in semen of a breeding bull compared to the distribution in feces, tissue and blood by IS900 and F57 quantitative real-time PCR and culture examinations. J. Vet. Med. Sci. Jpn. Soc. Vet. Sci. 2010, 72, 1283-1288.

21. Buergelt, C.D.; Donovan, G.A.; Williams, J.E. Identification of Mycobacterium avium subspecies paratuberculosis by Polymerase Chain Reaction in Blood and Semen of a Bull with Clinical Paratuberculosis. Int. J. Appl. Res. Vet. Med. 2004, 2, 130-134.

22. Ayele, W.Y.; Bartos, M.; Svastova, P.; Pavlik, I. Distribution of Mycobacterium avium subsp. paratuberculosis in organs of naturally infected bull-calves and breeding bulls. Vet. Microbiol. 2004, 103, 209-217.

23. Larsen, A.B.; Stalheim, O.H.V.; Hughes, D.E.; Appell, L.H.; Richards, W.D.; Himes, E.M. Mycobacterium paratuberculosis in the Semen and Genital Organs of a Semen-Donor Bull. J. Am. Vet. Med. Assoc. 1981, 179, 169-171.

24. Larsen, A.B.; Kopecky, K.E. Mycobacterium paratuberculosis in reproductive organs and semen of bulls. Am.J. Vet. Res. 1970, 31, 255-258.

25. Sorge, U.S.; Kurnick, S.; Sreevatsan, S. Detection of Mycobacterium avium subspecies paratuberculosis in the saliva of dairy cows: A pilot study. Vet. Microbiol. 2013, 164, 383-386.

26. Windsor, P.A.; Whittington, R.J. Evidence for age susceptibility of cattle to Johne's disease. Vet. J. 2010, 184, 37-44.

27. Mitchell, R.M.; Medley, G.F.; Collins, M.T.; Schukken, Y.H. A meta-analysis of the effect of dose and age at exposure on shedding of Mycobacterium avium subspecies paratuberculosis (MAP) in experimentally infected calves and cows. Epidemiol. Infect. 2011, 28, 1-16.

28. Merkal, R.S.; Miller, J.M.; Hintz, A.M.; Bryner, J.H. Intrauterine inoculation of Mycobacterium paratuberculosis into guinea pigs and cattle. Am. J. Vet. Res. 1982, 43, 676-678.

29. Owen, W.J.; Thoen, C.O. Experimental exposure of cattle to Mycobacterium paratuberculosis orally and intrauterine with attempted culture of the organs and detection of humoral antibodies. Proc. USA Health Assoc. 1983, 87, 570-581.

30. Wells, S.J.; Wagner, B.A. Herd-level risk factors for infection with Mycobacterium paratuberculosis in US dairies and association between familiarity of the herd manager with the disease or prior diagnosis of the disease in that herd and use of preventive measures. JAVMA $\mathbf{2 0 0 0}$, 219, 1450-1457.

31. Tiwari, A.; VanLeeuwen, J.A.; Dohoo, I.R.; Keefe, G.P.; Haddad, J.P.; Scott, H.M.; Whiting, T. Risk factors associated with Mycobacterium avium subspecies paratuberculosis seropositivity in Canadian dairy cows and herds. Prev. Vet. Med. 2009, 88, 32-41.

32. Wraight, M.D.; McNeil, J.; Beggs, D.S.; Greenall, R.K.; Humphris, T.B.; Irwin, R.J.; Jagoe, S.P.; Jemmeson, A.; Morgan, W.F.; Brightling, P.; et al. Compliance of Victorian dairy farmers with current calf rearing recommendations for control of Johne's disease. Vet. Microbiol. 2000, 77 , 429-442.

33. Marcé, C.; Ezanno, P.; Seegers, H.; Pfeiffer, D.U.; Fourichon, C. Within-herd contact structure and transmission of Mycobacterium avium subspecies paratuberculosis in a persistently infected dairy cattle herd. Prev. Vet. Med. 2011, 100, 116-125. 
34. Diéguez, F.J.; Arnaiz, I.; Sanjuán, M.L.; Vilar, M.J.; Yus, E. Management practices associated with Mycobacterium avium subspecies paratuberculosis infection and the effects of the infection on dairy herds. Vet. Rec. 2008, 162, 614-617.

35. Van Roermund, H.J.W.; Bakker, D.; Willemsen, P.T.J.; de Jong, M.C.M. Horizontal transmission of Mycobacterium avium subsp. paratuberculosis in cattle in an experimental setting: Calves can transmit the infection to other calves. Vet. Microbiol. 2007, 122, 270-279.

36. Nielsen, S.S.; Bjerre, H.; Toft, N. Colostrum and Milk as Risk Factors for Infection with Mycobacterium avium subspecies paratuberculosis in Dairy Cattle. J. Dairy Sci. 2008, 91, 4610-4615.

37. Pithua, P.; Godden, S.M.; Wells, S.J.; Oakes, M.J. Efficacy of feeding plasma-derived commercial colostrum replacer for the prevention of transmission of Mycobacterium avium subsp paratuberculosis in Holstein calves. J. Am. Vet. Med. Assoc. 2009, 234, 1167-1176.

38. Muskens, J.; Elbers, A.R.W.; Van Weering, H.J.; Noordhuizen, J.P.T.M. Herd Management Practices Associated with Paratuberculosis Seroprevalence in Dutch Dairy Herds. J. Vet. Med. Ser. B 2003, 50, 372-377.

39. Word Organisation for Animal Health (OIE). Paratuberculosis (Johne's disease). In Manual of Diagnostic Tests and Vaccines for Terrestrial Animals, 7th ed.; Word Organization for Animal Health: Paris, France, 2012; Volume 1, pp. 276-291.

40. Clark, D.L., Jr.; Koziczkowski, J.J.; Radcliff, R.P.; Carlson, R.A.; Ellingson, J.L.E. Detection of Mycobacterium avium Subspecies paratuberculosis: Comparing Fecal Culture Versus Serum Enzyme-Linked Immunosorbent Assay and Direct Fecal Polymerase Chain Reaction. J. Dairy Sci. 2008, 91, 2620-2627.

41. Hendrick, S.; Duffield, T.; Kelton, D.; Leslie, K.; Lissemore, K.; Archambault, M. Evaluation of enzyme-linked immunosorbent assays performed on milk and serum samples for detection of paratuberculosis in lactating dairy cows. J. Am. Vet. Med. Assoc. 2005, 226, 424-428.

42. Nielsen, S.S.; Ersbøll, A.K. Age at Occurrence of Mycobacterium avium Subspecies paratuberculosis in Naturally Infected Dairy Cows. J. Dairy Sci. 2006, 89, 4557-4566.

43. Weber, M.F.; Kogut, J.; de Bree, J.; van Schaik, G.; Nielen, M. Age at which dairy cattle become Mycobacterium avium subsp. paratuberculosis faecal culture positive. Prev. Vet. Med. 2010, 97, 29-36.

44. Collins, M.T.; Wells, S.J.; Petrini, K.R.; Collins, J.E.; Schultz, R.D.; Whitlock, R.H. Evaluation of five antibody detection tests for diagnosis of bovine paratuberculosis. Clin. Diagn. Lab. Immunol. 2005, 12, 685-692.

45. McKenna, S.L.B.; Keefe, G.P.; Barkema, H.W.; Sockett, D.C. Evaluation of three ELISAs for Mycobacterium avium subsp. paratuberculosis using tissue and fecal culture as comparison standards. Vet. Microbiol. 2005, 110, 105-111.

46. Milner, A.R.; Mack, W.N.; Coates, K.J.; Hill, J.; Gill, I.; Sheldrick, P. The sensitivity and specificity of a modified ELISA for the diagnosis of Johne's disease from a field trial in cattle. Vet. Microbiol. 1990, 25, 193-198.

47. Whitlock, R.H.; Wells, S.J.; Sweeney, R.W.; Van Tiem, J. ELISA and fecal culture for paratuberculosis (Johne's disease): Sensitivity and specificity of each method. Vet. Microbiol. 2000, 77, 387-398. 
48. Lavers, C.; Keefe, G.P.; Mckenna, S.; Chaffer, M. Evaluation of environmental culture to determine herd status for Johne's disease on Atlantic Canadian dairy farms. In Proceedings of the 11th International Colloquium on Paratuberculosis (11ICP), Sydney, Australia, 5-10 February 2012; pp. 52-53.

49. Lombard, J.E.; Wagner, B.A.; Smith, R.L.; McCluskey, B.J. Evaluation of Environmental Sampling and Culture to Determine Mycobacterium avium subspecies paratuberculosis Distribution and Herd Infection Status on US Dairy Operations. J. Dairy Sci. 2006, 89, 4163-4171.

50. Nielsen, S.S.; Thamsborg, S.M.; Houe, H.; Bitsch, V. Bulk-tank milk ELISA antibodies for estimating the prevalence of paratuberculosis in Danish dairy herds. Prev. Vet. Med. 2000, 44, 1-7.

51. Groenendaal, H.; Nielen, M.; Hesselink, J.W. Development of the Dutch Johne's disease control program supported by a simulation model. Prev. Vet. Med. 2003, 60, 69-90.

52. Barker, R.A.; Barkema, H.W.; Fecteau, G.; Keefe, G.P.; Kelton, D.F. Johne's Disease Control in Canada-Coordinated Nationally-Delivered Provincially. In Proceedings of the 3rd ParaTB Forum, Sydney, Australia, 4 February 2012.

53. Barker, R. Optimising Canadian Dairy Farm Biosecurity-Leveraging Lessons Learned from the Canadian Johne's Disease Initiative (CJDI: 2010-2013); Canadian Animal Health Coalition (CJDI): Guelph, ON, Canada, 2013; unpublished work.

54. VanLeeuwen, J.A.; Keefe, G.P.; Tremblay, R.; Power, C.; Wichtel, J.J. Seroprevalence of infection with Mycobacterium avium subspecies paratuberculosis, bovine leukemia virus, and bovine viral diarrhea virus in maritime Canada dairy cattle. Can. Vet. J. 2001, 42, 193-198.

55. Atlantic Johne's Disease Initiative. Johne's Control Program Reaches Milestone. Available online: http://www.atlanticjohnes.ca/files/documents/InsertSpring2012V1.pdf(accessed on 24 April 2014).

56. Ministère de l'Agriculture des Pêcheries et de l'Alimentation (MAPAQ). Paratuberculose. Available online: http:/www.mapaq.gouv.qc.ca/fr/Productions/santeanimale/maladiesanimales/ paratuberculose/Pages/paratuberculose.aspx (accessed on 24 April 2014).

57. Hendrick, S.; Duffield, T.; Leslie, K.; Lissemore, K.; Archambault, M.; Kelton, D. The prevalence of milk and serum antibodies to Mycobacterium avium subspecies paratuberculosis in dairy herds in Ontario. Can. Vet. J. 2005, 46, 1126-1129.

58. Ontario Johne's Education and Management Assistance Program. Program Results. Available online: http://www.johnes.ca/program\%20results.htm (accessed on 24 April 2014).

59. VanLeeuwen, J.A.; Tiwari, A.; Plaizier, J.C.; Whiting, T.L. Seroprevalences of antibodies against bovine leukemia virus, bovine viral diarrhea virus, Mycobacterium avium subspecies paratuberculosis, and Neospora caninum in beef and dairy cattle in Manitoba. Can. Vet. J. 2006, 47, 783-786.

60. VanLeeuwen, J.A.; Forsythe, L.; Tiwari, A.; Chartier, R. Seroprevalence of antibodies against bovine leukemia virus, bovine viral diarrhea virus, Mycobacterium avium subspecies paratuberculosis, and Neospora caninum in dairy cattle in Saskatchewan. Can. Vet. J. 2005, 46, 56-58.

61. Sorensen, O.; Rawluk, S.; Wu, J.; Manninen, K.; Ollis, G. Mycobacterium paratuberculosis in dairy herds in Alberta. Can. Vet. J. 2003, 44, 221-226.

62. Scott, H.M.; Sorensen, O.; Wu, J.T.; Chow, E.Y.; Manninen, K.; VanLeeuwen, J.A. Seroprevalence of Mycobacterium avium subspecies paratuberculosis, Neospora caninum, Bovine leukemia virus, and Bovine viral diarrhea virus infection among dairy cattle and herds in Alberta and agroecological risk factors associated with seropositivity. Can. Vet. J. 2006, 47, 981-991. 
63. Alberta Johne's Disease Initiative. Johne's Disease-What's the Scoop? Available online: http://www.albertajohnes.ca/JDabout/MT_1401a.pdf (accessed on 24 April 2014).

64. Kijlstra, A.; Eijck, I. Animal health in organic livestock production systems: A review. Njas-Wageningen J. Life Sci. 2006, 54, 77-94.

65. Ramanantoanina, F.; Francoz, D.; Côté, G.; Labrecque, O.; Gagnon, A.C.; Beauchamp, G.; Fecteau, G. Seroprevalence of Mycobacterium avium subsp. Paratuberculosis, Neospora caninum, bovine viral diarrhea and infectious bovine rhinotracheitis viruses in Québec organic herds. In Proceedings of the XXVII World Buiatrics Congress, Lissabon, Portugal, 3-8 June 2012.

66. Sorge, U.S. An Overview Over the Organic Dairy Industry in Minnesota. In Proceedings of the 117th Annual Meeting of the Minnesota Veterinary Medical Association, Minneapolis, MN, USA, 6-8 February 2014.

67. Zwald, A.G.; Ruegg, P.L.; Kaneene, J.B.; Warnick, L.D.; Wells, S.J.; Fossler, C.; Halbert, L.W. Management practices and reported antimicrobial usage on conventional and organic dairy farms. J. Dairy Sci. 2004, 87, 191-201.

68. Sato, K.; Kaneene, J.B.; Erskine, R.J.; Bartlett, P.C. A comparison of production and management between Wisconsin organic and conventional dairy herds. Livest. Prod. Sci. 2005, 93, 105-115.

69. Pieper, L.; Godkin, A.; Sorge, U.; Lissemore, K.; DeVries, T.J.; Kelton, D. Prevalence of Mycobacterium avium subsp. paratuberculosis (MAP) ELISA-Positive Cows and Assessment of MAP Transmission Risk on Organic Dairy Farms in Ontario, Canada. In Proceedings of the 46th Annual Conference of the American Association of Bovine Practitioners (AABP), Milwaukee, WI, USA, 19-21 September 2013; pp. 156-157.

70. Stiglbauer, K.E.; Cicconi-Hogan, K.M.; Richert, R.; Schukken, Y.H.; Ruegg, P.L.; Gamroth, M. Assessment of herd management on organic and conventional dairy farms in the United States. J. Dairy Sci. 2013, 96, 1290-1300.

71. Hardeng, F.; Edge, V.L. Mastitis, ketosis, and milk fever in 31 organic and 93 conventional Norwegian dairy herds. J. Dairy Sci. 2001, 84, 2673-2679.

72. Sorge, U.S.; Lissemore, K.; Godkin, A.; Hendrick, S.; Wells, S.; Kelton, D. Associations between paratuberculosis milk ELISA result, milk production, and breed in Canadian dairy cows. J. Dairy Sci. 2011, 94, 754-761.

73. Jubb, T.F.; Sergeant, E.S.G.; Callinan, A.P.L.; Galvin, J.W. Estimate of the sensitivity of an ELISA used to detect Johne's disease in Victorian dairy cattle herds. Aust. Vet. J. 2004, 82, 569-573.

74. Dhand, N.K.; Eppleston, J.; Whittington, R.J.; Toribio, J.-A.L.M.L. Association of farm soil characteristics with ovine Johne's disease in Australia. Prev. Vet. Med. 2009, 89, 110-120.

75. Grewal, S.K.; Rajeev, S.; Sreevatsan, S.; Michel, F.C., Jr. Persistence of Mycobacterium avium subsp. paratuberculosis and other zoonotic pathogens during simulated composting, manure packing, and liquid storage of dairy manure. Appl. Environ. Microbiol. 2006, 72, 565-574.

76. Tkachuk, V.L.; Krause, D.O.; McAllister, T.A.; Buckley, K.E.; Reuter, T.; Hendrick, S.; Ominski, K.H. Assessing the inactivation of Mycobacterium avium subsp. paratuberculosis during composting of livestock carcasses. Appl. Environ. Microbiol. 2013, 79, 3215-3224.

77. Di Rosa, M.; Malaguarnera, M.; Nicoletti, F.; Malaguarnera, L. Vitamin D3: A helpful immuno-modulator. Immunology 2011, 134, 123-139. 
78. Sorge, U.S.; Molitor, T.; Linn, J.; Gallaher, D.; Wells, S.W. Cow-level association between serum 25-hydroxyvitamin D concentration and Mycobacterium avium subspecies paratuberculosis antibody seropositivity: A pilot study. J. Dairy Sci. 2013, 96, 1030-1037.

79. Cetinkaya, B.; Erdogan, H.M.; Morgan, K.L. Relationships between the presence of Johne's disease and farm and management factors in dairy cattle in England. Prev. Vet. Med. 1997, 32, 253-266.

80. Whittington, R.J.; Marshall, D.J.; Nicholls, P.J.; Marsh, I.B.; Reddacliff, L.A. Survival and Dormancy of Mycobacterium avium subsp. paratuberculosis in the Environment. Appl. Environ. Microbiol. 2004, 70, 2989-3004.

81. Thamsborg, S.M.; Roepstorff, A.; Larsen, M. Integrated and biological control of parasites in organic and conventional production systems. Vet. Parasitol. 1999, 84, 169-186.

82. Whittington, R.J.; Marsh, I.B.; Reddacliff, L.A. Survival of Mycobacterium avium subsp. paratuberculosis in dam water and sediment. Appl. Environ. Microbiol. 2005, 71, 5304-5308.

83. Johnson-Ifearulundu, Y.J.; Kaneene, J.B. Management-related risk factors for M. paratuberculosis infection in Michigan, USA, dairy herds. Prev. Vet. Med. 1998, 37, 41-54.

84. Baptista, F.M.; Nielsen, S.S.; Toft, N. Association Between the Presence of Antibodies to Mycobacterium avium subspecies paratuberculosis and Somatic Cell Count. J. Dairy Sci. 2008, 91, 109-118.

85. Tavornpanich, S.; Johnson, W.O.; Anderson, R.J.; Gardner, I.A. Herd characteristics and management practices associated with seroprevalence of Mycobacterium avium subsp. paratuberculosis infection in dairy herds. Am. J. Vet. Res. 2008, 69, 904-911.

86. Duve, L.R.; Weary, D.M.; Halekoh, U.; Jensen, M.B. The effects of social contact and milk allowance on responses to handling, play, and social behavior in young dairy calves. J. Dairy Sci. 2012, 95, 6571-6581.

87. Hendrick, S.H.; Kelton, D.F.; Leslie, K.E.; Lissemore, K.D.; Archambault, M.; Bagg, R.; Dick, P.; Duffield, T.F. Efficacy of monensin sodium for the reduction of fecal shedding of Mycobacterium avium subsp. paratuberculosis in infected dairy cattle. Prev. Vet. Med. 2006, 75, 206-220.

88. Hendrick, S.H.; Duffield, T.F.; Leslie, K.E.; Lissemore, K.D.; Archambault, M.; Bagg, R.; Dick, P.; Kelton, D.F. Monensin might protect Ontario, Canada dairy cows from paratuberculosis milk-ELISA positivity. Prev. Vet. Med. 2006, 76, 237-248.

89. Wagenaar, J.P.; Klocke, P.; Butler, G.; Smolders, G.; Nielsen, J.H.; Canever, A.; Leifert, C. Effect of production system, alternative treatments and calf rearing system on udder health in organic dairy cows. Njas-Wageningen J. Life Sci. 2011, 58, 157-162.

90. Ruegg, P.L. Management of mastitis on organic and conventional dairy farms. J. Anim. Sci. 2009, $87,43-55$.

91. Richert, R.M.; Cicconi, K.M.; Gamroth, M.J.; Schukken, Y.H.; Stiglbauer, K.E.; Ruegg, P.L. Management factors associated with veterinary usage by organic and conventional dairy farms. J. Am. Vet. Med. Assoc. 2013, 242, 1732-1743.

92. Kelton, D.; Perkins, N.; Godkin, A.; MacNaughton, G.; Cantin, R.; Hand, K. Comparison of Participants and Non-Participants in a Voluntary Johne's Disease Control Program in Ontario, Canada. In Proceedings of the 11th International Colloquium on Paratuberculosis (11ICP), Sydney, Australia, 5-10 February 2012. 
93. Thompson-Crispi, K.A.; Hine, B.; Quinton, M.; Miglior, F.; Mallard, B.A. Short communication: Association of disease incidence and adaptive immune response in Holstein dairy cows. J. Dairy Sci. 2012, 95, 3888-3893.

94. Pinedo, P.J.; Donovan, G.A.; Rae, O.; de la Paz, J. Association between Paratuberculosis Infection and General Immune Status in Dairy Cattle. In Proceedings of the 10th International Colloquium for Paratuberculosis, Minneapolis, MN, USA, 9-14 August 2009; p. 127.

95. Van Hulzen, K.J.E.; Koets, A.P.; Nielen, M.; Heuven, H.C.M.; van Arendonk, J.A.M.; Klinkenberg, D. The effect of genetic selection for Johne's disease resistance in dairy cattle: Results of a genetic-epidemiological model. J. Dairy Sci. 2014, 97, 1762-1773.

96. Chi, J.; VanLeeuwen, J.A.; Weersink, A.; Keefe, G.P. Management factors related to seroprevalences to bovine viral-diarrhoea virus, bovine-leukosis virus, Mycobacterium avium subspecies paratuberculosis, and Neospora caninum in dairy herds in the Canadian Maritimes. Prev. Vet. Med. 2002, 55, 57-68.

97. Glawischnig, W.; Awad-Masalmeh, M.; Khaschabi, D.; Schoenbauer, M. [Detection fo Mycobacterium avium subsp. paratuberculosis from the testicles of a clinically infected breeding bull]. Berl. Muench. Tieraerztl. Wschr. 2004, 117, 136-139. (In German)

98. Lombard, J.E.; Byrem, T.M.; Wagner, B.A.; McCluskey, B.J. Comparison of milk and serum enzyme-linked immunosorbent assays for diagnosis of Mycobacterium avium subspecies paratuberculosis infection in dairy cattle. J. Vet. Diagn. Invest. 2006, 18, 448-458.

(C) 2014 by the authors; licensee MDPI, Basel, Switzerland. This article is an open access article distributed under the terms and conditions of the Creative Commons Attribution license (http://creativecommons.org/licenses/by/4.0/). 